\title{
The VP-Split Analysis and Unaccusativity: A Comparative Study of Classical Arabic and Modern English
}

\author{
Marwa Mahmoud Abdel Wahed*
}

\section{Prof. Wafaa Abdel Fahim Batran**}

\begin{abstract}
This paper aims at investigating and analyzing the different verb forms of the triliteral Arabic verb that exhibit typical characteristics of unaccusative predicates. Through providing evidence, it will be shown that Form 1 with its three variants, denominative verbs in Form 4 and, finally, Form 9 of the triliteral Arabic verbs all display typical traits of unaccusatives Furthermore, by investigating unaccusativty in Arabic triliteral verbs, this study provides concrete and crucial evidence that argument structure is the same in all languages. Argument structure (the verb and the arguments it takes) is a universal property (Principles) and the surface structure is parametric (Parameters). Moreover, this paper attempts to prove that the VP-Split hypothesis can provide a unified structural analysis of the argument structure of the unaccusative verb in Classical Arabic as it does in Modern English This study is conducted within Chomsky's Principles and Parameters Framework (Chomsky 1981, 1982, 1991, 1993) and the Minimalist Program (1995).
\end{abstract}

** Department of English Language and Literature, Faculty of Women, Ain Shams University marwa.mahmoud@women.asu.edu.eg

**Department of English Language and Literature, Faculty of Women, Ain Shams University wbwahba1952@yahoo.com 


\section{Language \& Literature}

Keywords: unaccusativity, VP-Split analysis, Arabic triliteral verbs, Principles and Parameters, Minimalist Program.

\section{Introduction}

The typology of verbs in this paper is based on the argument structure of each verb. The typology of the English verb with respect to its argument structure according to Chomsky's theory is as follows: (i) unergative/ intransitive verb (oneplace predicate), (ii) unaccusative verb (one- place predicate), (iii) transitive verb (two- place predicate), (iv) ditransitive verb (three- place predicate) and (v) ergative verb (two- place predicate).

Regarding verbs which take only one argument, Perlmutter (1978) (also Burzio 1981 and inter alia) proposed in his Unaccusative Hypothesis that there are two types of intransitive verbs, unergative verbs and unaccusative verbs. The difference between them is that the only argument of an unergative verb base generates as its subject / external argument, whereas the single argument of an unaccusative verb originates in its object / internal complement position. As the unaccusative verb fails to assign accusative case to its complement, it gets raised to the Spec of the light $\mathrm{v}$ and gets the nominative case by being c-commanded by $\mathrm{T}$. 


\section{Language \& Literature}

As for transitive verbs, they are predicates which contain two arguments in their theta grids, one as its subject/ external argument and the other as its object/ internal argument. Ditransitive verbs, such as the verb 'give', require three arguments, one subject/ external argument and two objects/ internal complements. Finally, there is a class of verbs which can occur transitively or intransitively, and the subject of the intransitive alternate plays the same thematic role as the complement of the transitive alternate. Such verbs, as 'break' and 'open', are called ergative verbs. This term was initially used to refer to languages in which the subject of the intransitive verb relates to the complement of the transitive verb by carrying the same morphological case (Comrie 1978 and inter alia). Furthermore, it has to be mentioned that unaccusative verbs and the intransitive alternate of the ergative verbs are differentiated by two points. On one hand, unaccusative verbs do not occur transitively, but ergative verbs do. On the other hand, ergative verbs cannot allow the insertion of expletive 'there' in the Spec- TP position, but unaccusative verbs can.

In contrast, according to Arabic linguistic theory the triliteral verb is divided into three radicals (consonants) and variable phonemes (Wright 1896). The argument structure of the verb is implicit in each of the nine forms of the triliteral class. The verb form in Arabic through its derivational morphology comprises its

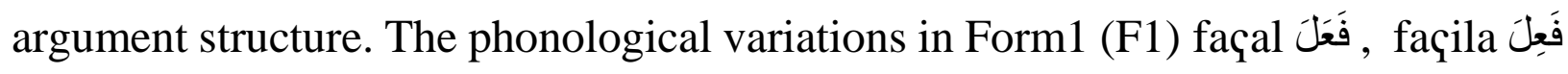

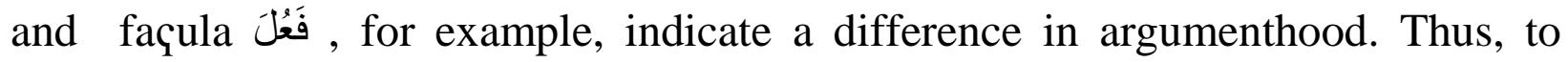
investigate the argument structure of verbs in Classical Arabic, one has to deal with phonology- morphology- syntax- semantics interface.

In order to study the argument structure of verbs, one has to state the fact that verbs in English and Arabic belong to two different morphological types. The 


\section{Language \& Literature}

verb in English has a concatenative nature (McCarthy 1981). Hence, the base cannot be broken into smaller units, and the only morphological operations allowed here are prefixation, suffixation and in rare examples infixation. In contrast, the verb form in Arabic has a non- concatenative nature, i.e. the radicals

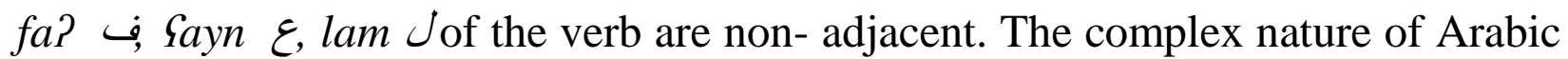
morphology determines the argument structure of the verb in conjunction with the phonological variations as illustrated in the following paradigm. The three variations belong to Form 1(F1) of the triliteral verb. The phonological alternations in the middle vowel in the verb are not allophones. They are phonemes as they determine the argument structure of the verb. 


\section{Language \& Literature}

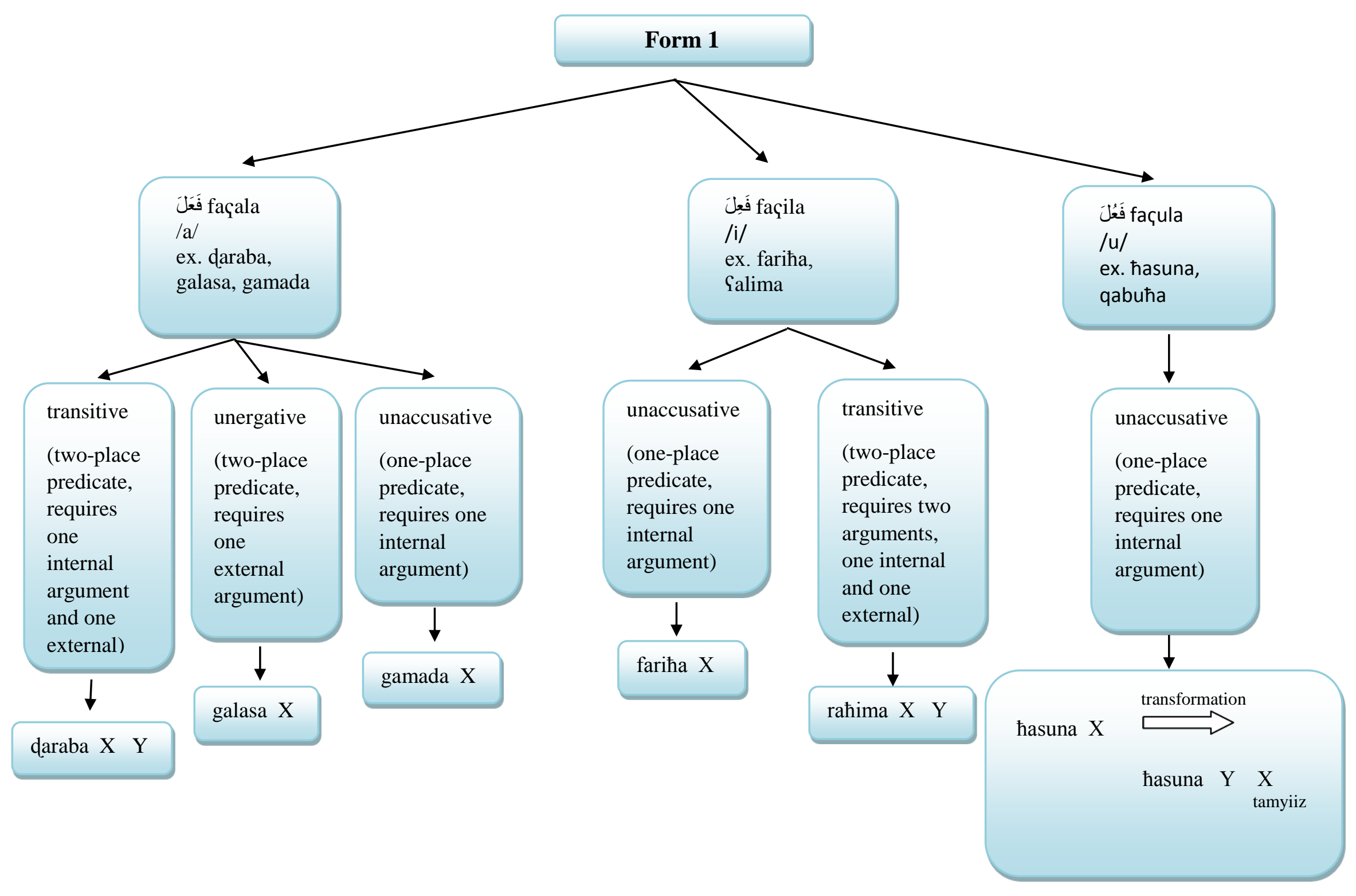




\section{Language \& Literature}

Linguistic Theory in both English and Arabic makes a distinction between the syntactic subject and the thematic subject and this distinction is universal. Consider the following example.

(1) There are three men in the room.

There is the syntactic subject, but three men is the thematic subject. The same thing is in the third derivation in F1. Hence, in the Arabic sentence in (2) the thematic subject is wagh and Zayd is the syntactic one.

(2) hasuna Zayd-un wagh-an

to be beautiful Zayd-nom face-acc Zayd is beautiful in his face.

A syntactic evidence is clear in the following sentence where wagh originate as the syntactic subject, as well as being the thematic one.

(3) hasuna wagh-u Zayd-in

to be beautiful face-nom Zayd-gen

Zayd's face is beautiful.

(4) hasuna

al-wagh-u

to be beautiful the-face-nom

The face is beautiful.

\section{Study Questions}

a) Which verb forms of the triliteral Arabic verb exhibit typical characteristics of unaccusative predicates? 


\section{Language \& Literature}

b) Can the VP- Split hypothesis provide a unified structural analysis of the argument structure of the unaccusative verb in Classical Arabic?

\section{Theoretical Framework}

This research is carried out within the framework of Chomsky's Principles and Parameters $(1981,1982,1991,1993)$ and the Minimalist Program (1995).

The Principles and Parameters (P\&P) approach to syntax seeks to describe principles that appear to be invariant across human languages (Chomsky 1981; 1995), and to characterize in a precise manner the parameters of possible variations among languages. Hence, $\mathrm{P} \& \mathrm{P}$ attempts at a theory both of universal grammar and language - particular grammars. To illustrate, one of the universal principles is the Extended Projection Principle (EPP) which posits that every T constituent must be extended into a TP projection which has a specifier. In other words, every sentence must have a subject in all languages. On the other hand, one parameter of variation among languages is the null- subject parameter. Arabic has this parameter, but English does not.

Chomsky's Minimalist Program (MP) (Chomsky 1995) aims to minimize the theoretical machinery needed for derivation as much as possible. It eliminates DS and SS. MP takes language to consist of the lexicon and a computational system. The computational system selects items from the lexicon and constructs

derivations that have to meet the interface conditions at LF and PF. The items merge to form phrase markers, and then categories move and merge with targeted categories in a strictly cyclic way.

\section{The Arabic linguistic Tradition}




\section{Language \& Literature}

The Arabic grammatical tradition is considered one of the great traditions in the history of linguistics, and it shares a number of fundamental similarities with modern linguistic theory (Owens 1988). This study is mainly concerned with the standardized Arabic linguistic theory/tradition concerning the morphology of the verb (Sibawayh V.4, Ibn YaYish V.7, Ibn Hisham, Al-Morada).

The pervasive pattern of verbs in Arabic is the triliteral verb (Wright 1896), in other words, verbs which contain three radical letters (consonants). There are also quadrilateral verbs. It is from the base form of the triliteral and quadriliteral verbs that other forms are derived in various ways. Such variations lead to modifications in the idea conveyed by the ground- form, and implicitly to effects on the argument structure of the verb. The derived forms of the triliteral verb are as follows.
I. فَعَلَ (faSala)
II. فَعَّل (faSYala)
III. فَاعَلَ (faaSala)
IV. أَفَعَلْ (PafSala)

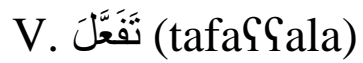
VI. تَفَاعَلَ (tafaaYala)
VII. إنفَعَل (PinfaSala)
VIII. افتَََْلَ (PiftaSala)
IX. إِفَلَّلَ (PifYalla)
X. إِتَفَعَلَ (Pistafৎala)
XI. إفعَالَّ (PifGaalla)
XII. إفعَو عَلَ (PifCawSala)

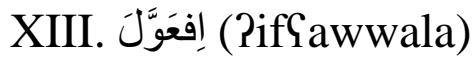
XIV. إفحَنَلَلَ (PifSanlala)
XV. إفحَنَلَى (PifGanla)

This paper is limited to Forms $1-9$ of the triliteral verb. Added to that, the $3^{\text {rd }}$ per. sing. masc. perf. is used in the examples as it is considered the simplest form of the verb.

\section{The VP-Split Hypothesis}

The VP-Shell (split VP) analysis was first introduced by Larson (1988). According to that hypothesis, VPs should be split into two distinct projections- an outer shell and an inner core, as illustrated in the example below.

(5) (a) They roll the ball down the hill. 
(b)

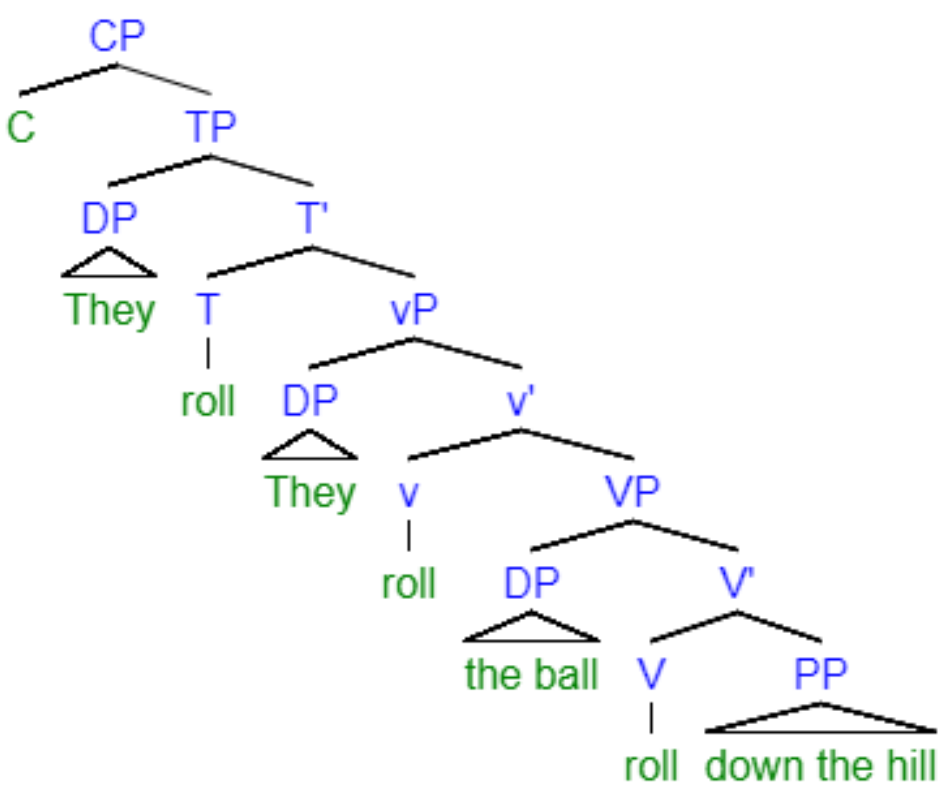

The structure in the tree above shows that the verb roll merges with its complement down the hill to form a V' constituent. That resulting V' merges with its subject to form the VP (the core). The causative light verb (v) is a strong affix, and it attracts the verb roll and the abstract causative, forming v' which then merges with the subject they to form the complex vP (the shell).

The VP-Split hypothesis (Larson 1988 and inter alia) captures the argument structure of the non- concatenative behavior of the Arabic verb as well as the concatenative behavior of the English verb. The VP in Arabic is split into the core VP which includes the base verb (الفعل المجرد), whereas the light vP (the outer shell) contains the affixes (المزيد) which determine the argument structure of the verb. The following tree diagram in (4) presents an example of such analysis. 


\section{Language \& Literature}

(6) (a) xarraga

al-ragul-u

al-walad-a

make to go out the man-nom the boy-acc

The man made the boy go out.

(b)

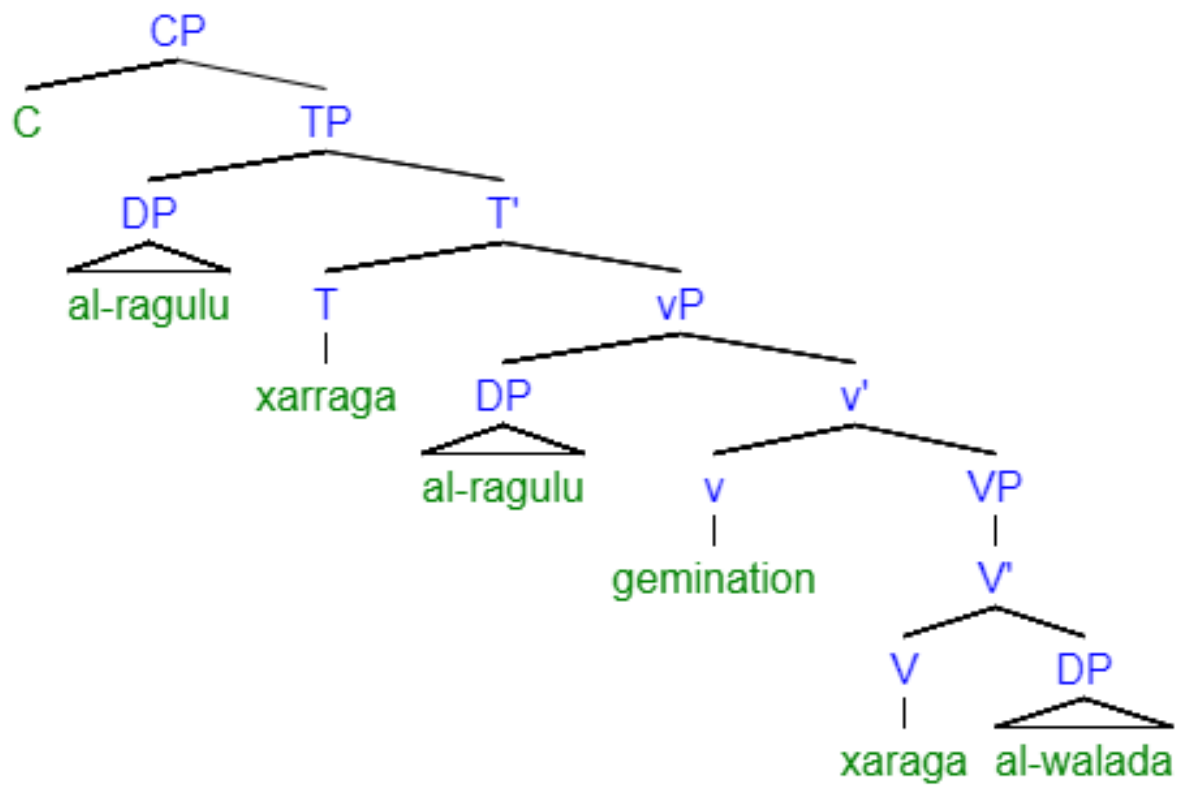

\section{Unaccusativity}

Perlmutter (1978) (also Burzio 1981 and inter alia) proposed in his Unaccusative Hypothesis that intransitive verbs like come and arrive, amongst others, are unaccusative predicates. The single argument of an unaccusative verb originates as the internal complement of the lexical V. As the unaccusative verb fails to assign accusative case to its complement, it gets raised to the Spec of the light $\mathrm{v}$ and gets the nominative case by being c-commanded by $\mathrm{T}$. The VP split hypothesis provides a unified analysis for such structures. A well-established concept in the literature about the diagnostics of unaccusatives are illustrated in Edelstein (2020), as shown below. 


\section{Buhuth Journal \\ Issue Three - Part Three (2021) \\ Language \& Literature}

(7) (a) A train arrived from Luxor

(b)

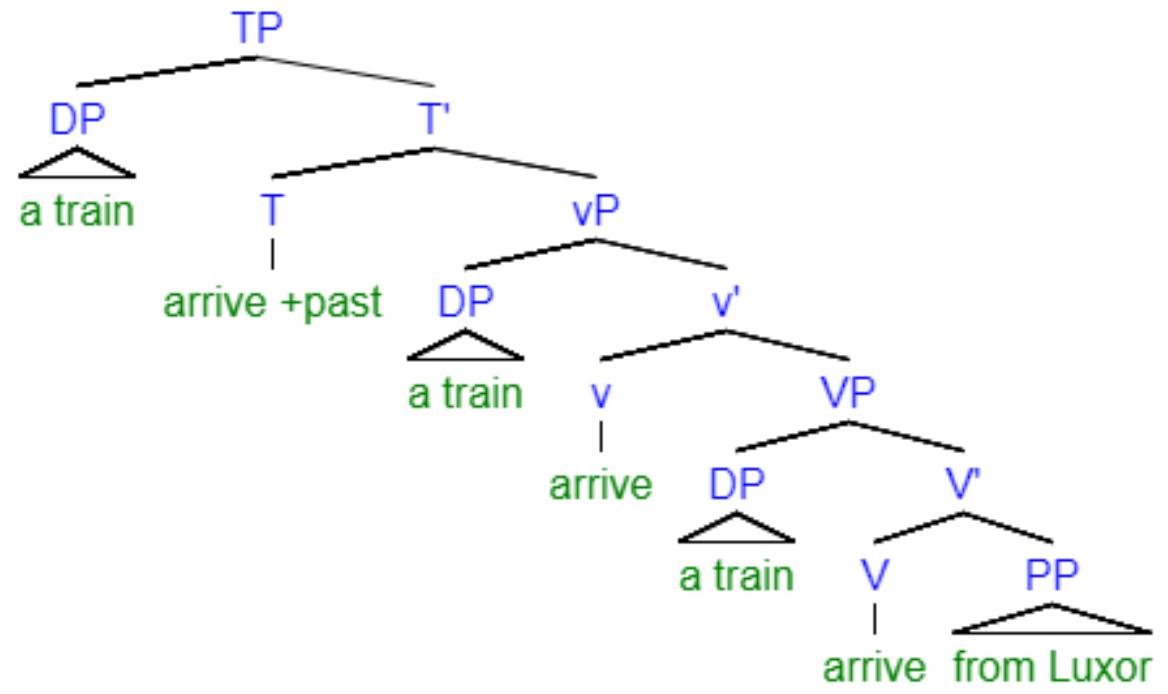

Another realization of unaccusative structures is when the DP theme argument of the verb remains in-situ and expletive 'there' is inserted in the Spec-v (which is with no external argument), resulting in the following sentence.

(8) (a) There arrived a train from Luxor

(b) 


\section{Language \& Literature}

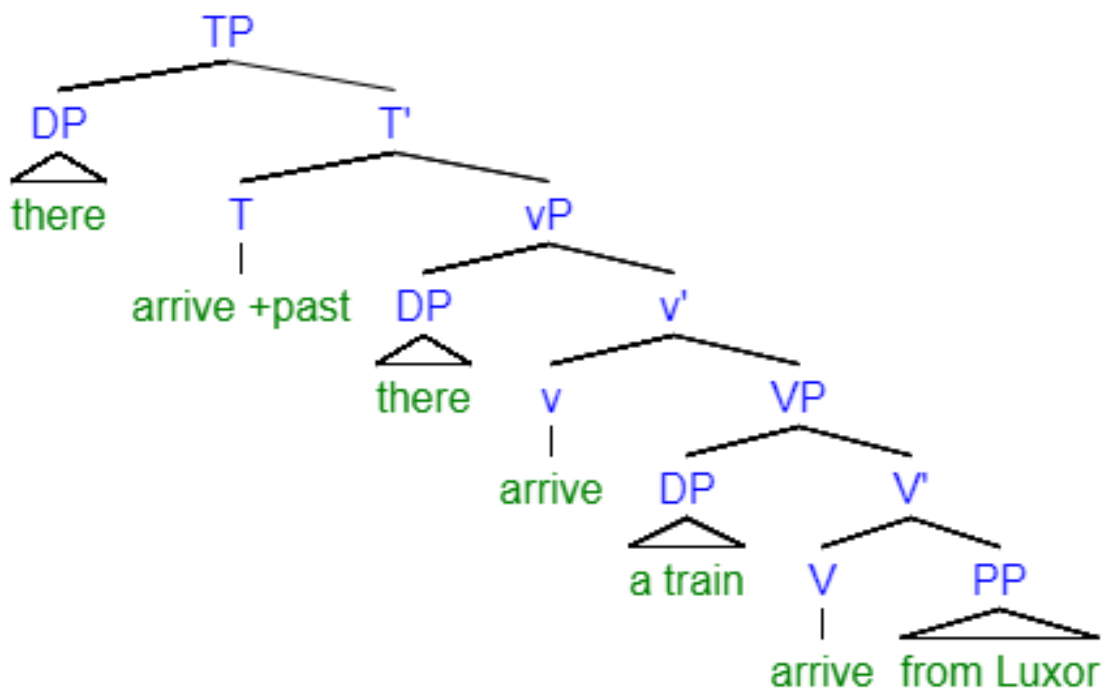

In addition, unaccusative verbs allow locative inversion constructions, where the PP locative argument is inserted in the Spec- TP position and the DP theme argument is kept in the complement position of the VP. This is exemplified in the following sentence.

(9) (a) From Luxor arrived a train.

(b) 


\section{Language \& Literature}

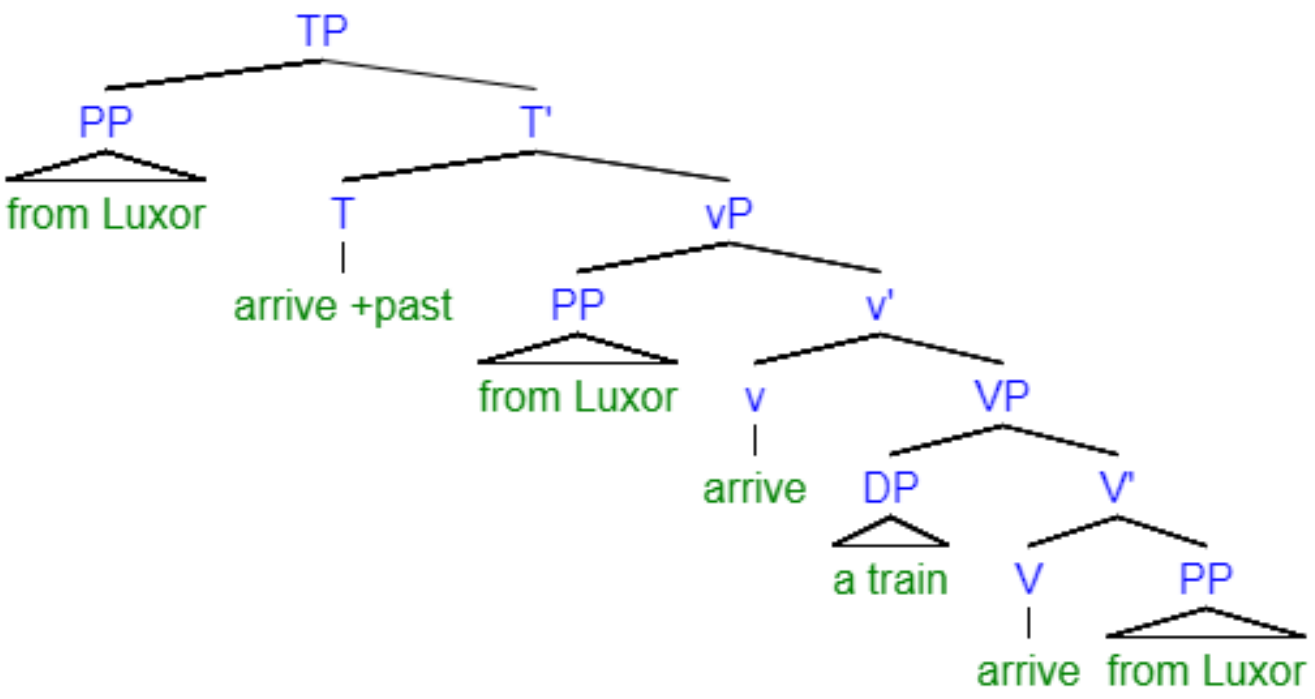

Finally, as unaccusative verbs cannot specifically assign the agent theta role to their only DP argument, the usage of adverbs like '(un)deliberately' and '(un)intentionally' generates unmeaningful sentences, as in the following example.

*A train deliberately arrived from Luxor.

\section{Unaccusativity in Arabic Triliteral Verbs}

\section{Form 1 Variant A faSala فَعَل}

Whenever /a/ occurs as the second vowel in F1, it normally denotes a transitive verb. However, there are other cases where the verb is unergative, ditransitive, or unaccusative. The following examples in (7), (8) and (9) illustrate how F1 Variant $A$ verbs behave as unaccusative predicates.

(a) gamada al-nahr-u freeze the river-nom The river froze.

(b) 


\section{Buhuth Journal \\ Issue Three - Part Three (2021)}

\section{Language \& Literature}

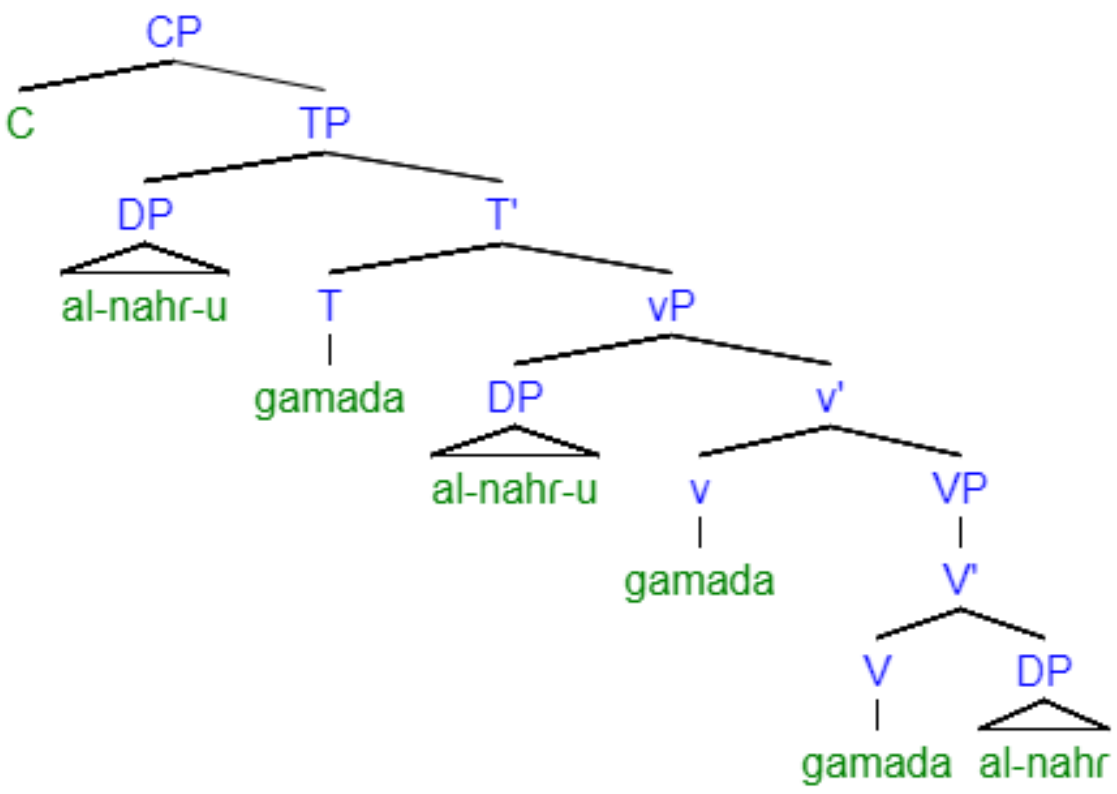

(12)
(a) saaPa Zayd-un ragul-an
to be bad Zayd-nom man-acc
Zayd is bad as a man.

(b) 


\section{Language \& Literature}

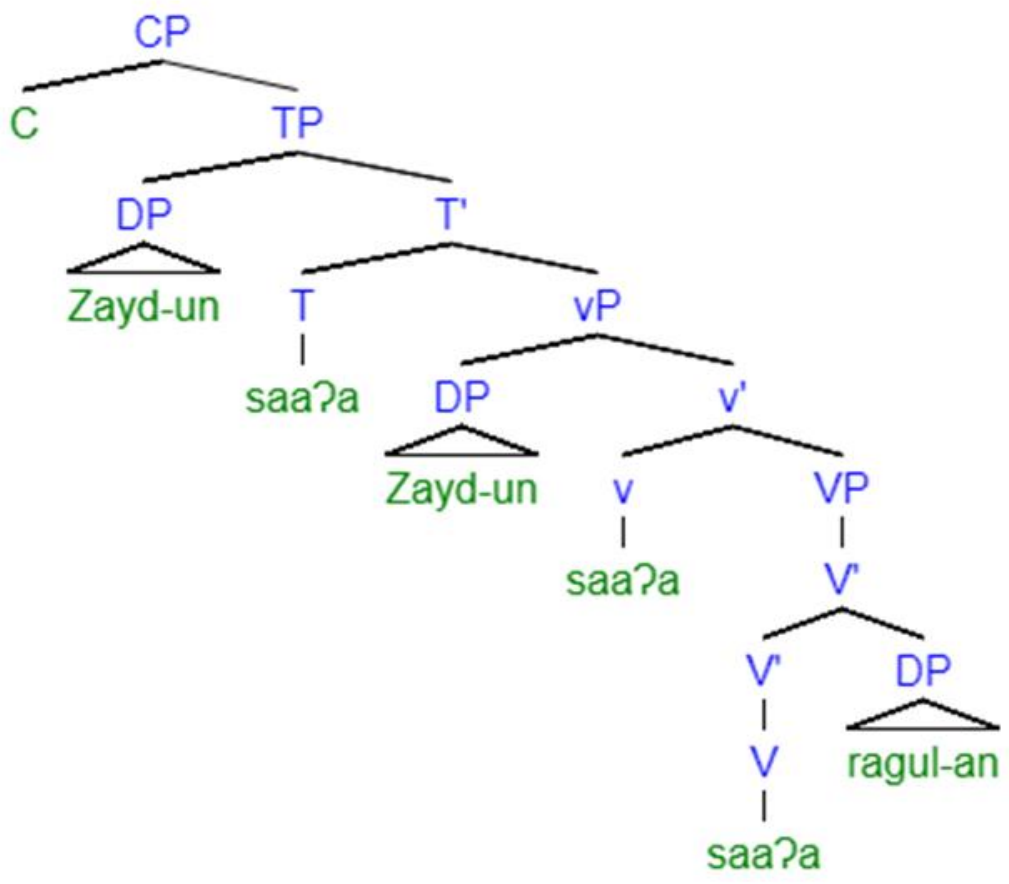

(13)

"ساء مثناً القوم الذين كذبو ا بآياتنا"
saa?a
matal-an Pal-qawm-u
Pallaðiin-a kaððab-uu
bi-Paayaatin-aa
be evil example-acc the-people-nom who
reject-they-nom
with-signs-our-obl

Evil as an example are people who reject Our signs

(Al-Araf: Verse 177 (translation by Abdullah Yusuf Ali))

The verbs gamada (to freeze), saa?a (to be bad) in examples (11), (12) and (13) can be considered typical unaccusatives. Their single arguments, al-nahr-u (theriver-nom), Zayd-un (Zayd-nom), and Pal-qawm-u (the-people-nom) respectively, originate as the complement of the lexical verb. Then, as the verb fails to assign the accusative case to its internal argument, it gets raised to the Spec of the vP to receive the nominative case from the c-commanding T. Furthermore, they allow 'tamyiiz'/ resultative predicates, as ragul-an (man-acc) in (12) and maAal-an (example-acc) in (13). A syntactic diagnostic of unaccusatives in Classical Arabic 


\section{Language \& Literature}

is that they allow a resultative predicate, which, unlike depictive predicates, is semantically linked to the main verb.

\section{Form 1 Variant B facila فَ}

In variant $\mathrm{B}$, fasila, there is a phonological alternation. Instead of the low front vowel /a/ in variant A faSala, the high front vowel /i/ exists as the second intervening vowel. This vocalic change affects the argument structure of the verb. If the second vowel is /i/, the verb is generally a one- place predicate that indicates

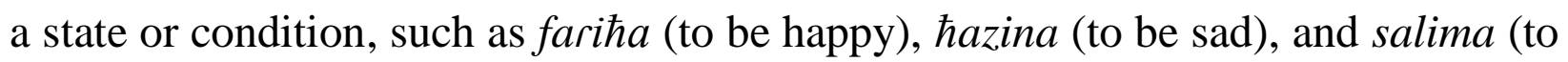
be safe). Its only DP argument is assigned the $\theta$-roles Patient or Theme, so it originates internally as the complement of the lexical V. Thus, verbs in F1 Variant $B$ exhibit typical characteristics of unaccusatives. This is exemplified in sentence (14a) and its tree diagram presentation in (14b).

(a) fariћa al-ragul-u

to be happy the man-nom

The man was happy.

(b) 


\section{Language \& Literature}

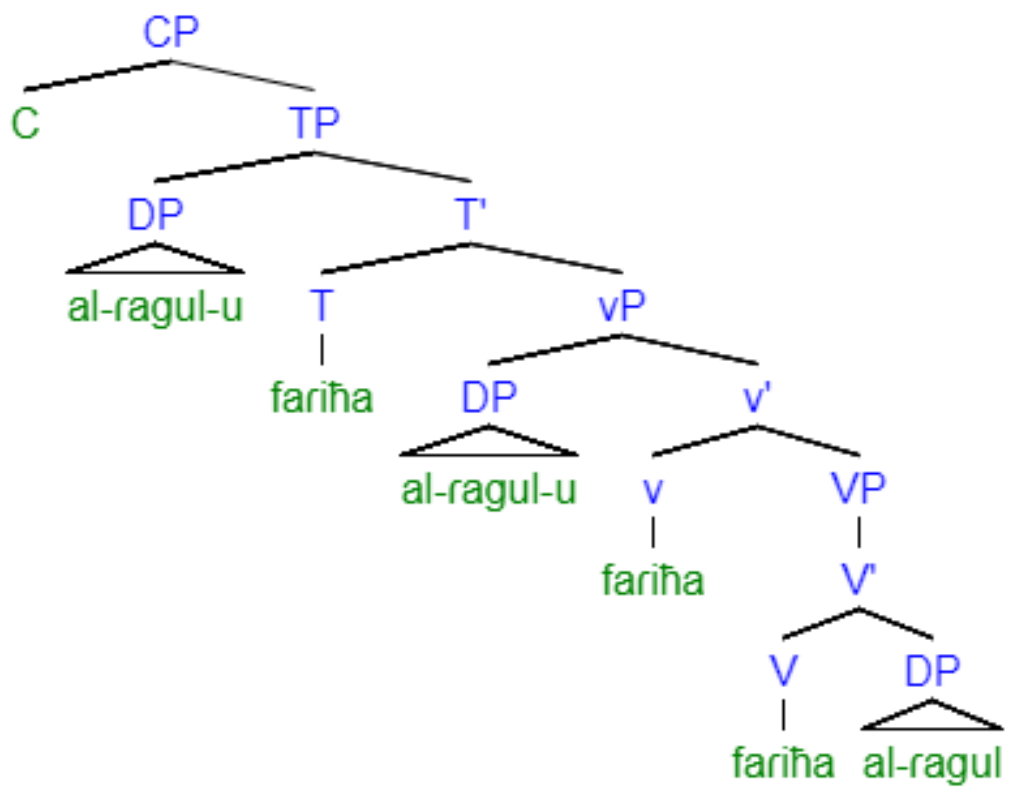

Another diagnostic for unaccusativity in F1 Variant $B$ verbs is the generation of unmeaningful sentences when used with the adjuncts Samdan and qasdan, which are the Arabic counterparts of 'deliberately' and 'intentionally', as illustrated in the example below.

$$
\begin{aligned}
& \text { *salima al-ragul-u Camdan. } \\
& \text { to be safe the-man-nom deliberately } \\
& \text { *The man was safe deliberately. }
\end{aligned}
$$

\section{Form 1 Variant C faSula فُ}

Invariably, the third version of $\mathrm{F} 1$, with the epenthetic vowel $/ \mathrm{u} /$, requires one argument only. Consider the following paradigm that exemplifies the third variant $/ \mathrm{u} /$.
(16)
hasuna
Zayd-un
wagh-an
to be handsome Zayd-nom
face-acc
Zayd was handsome. 


\section{Language \& Literature}

hasuna wagh-u
to be handsome face-nom
Zayd's face was handsome.

(18)
hasuna
al-wagh-u
to be beautiful
the face-nom
The face was handsome.

The verb hasuna is a one- place predicate. The sentence in (15) is transformationally derived from the sentence in (16). The external argument of Fasuna is not Zayd, it is wagh. The genitive complement Zayd in (16) becomes the syntactic subject in (15), whereas the thematic subject in (16) wagh becomes 'tamyiiz'/ resultative predicate in (15). In (17) the argument al-wagh is simply definite and as such the sentence is complete. Hence, it is said that the three sentences (15), (16) and (17) have the same argument structure despite their syntactic differences. This is shown in the following tree diagrams. 
Buhuth Journal Issue Three - Part Three (2021)

\section{Language \& Literature}

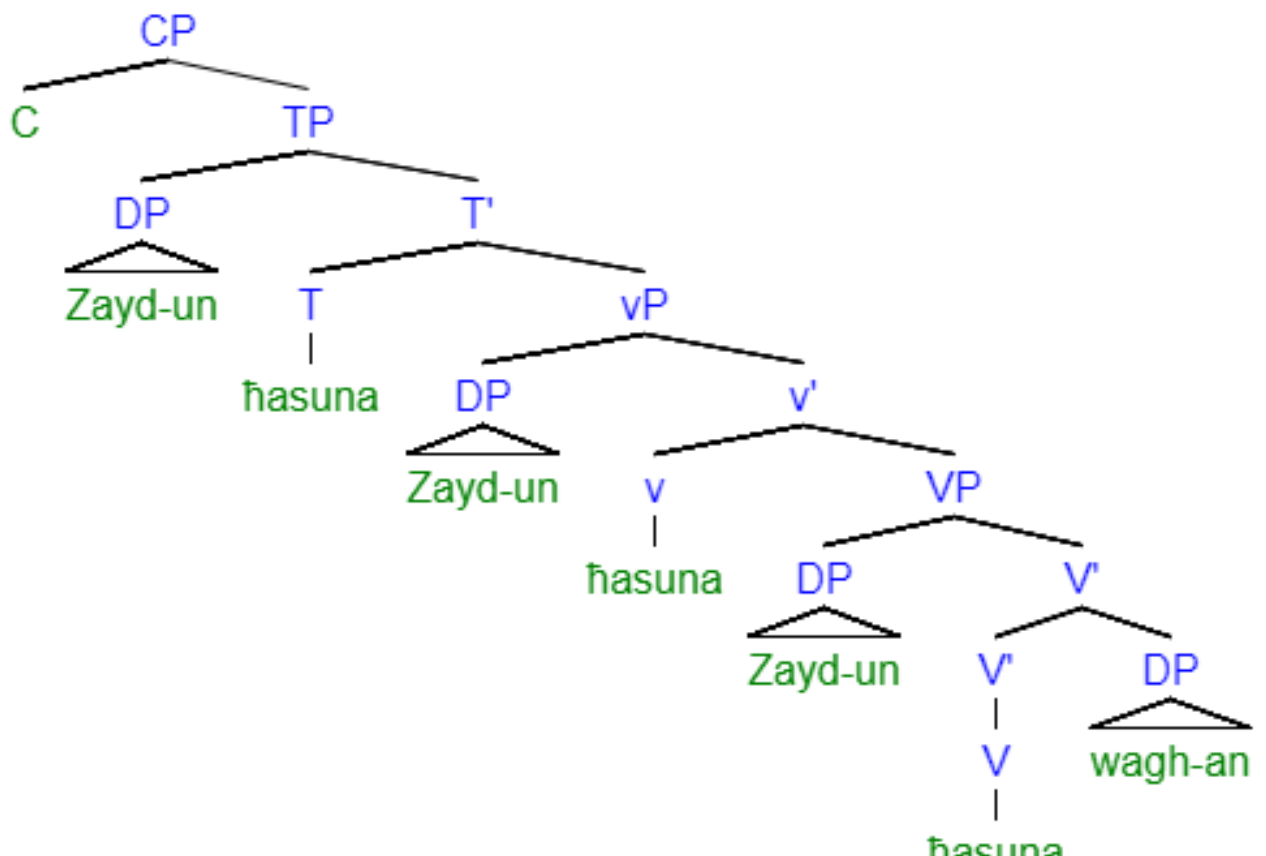

ћasuna

(20) 


\section{Language \& Literature}

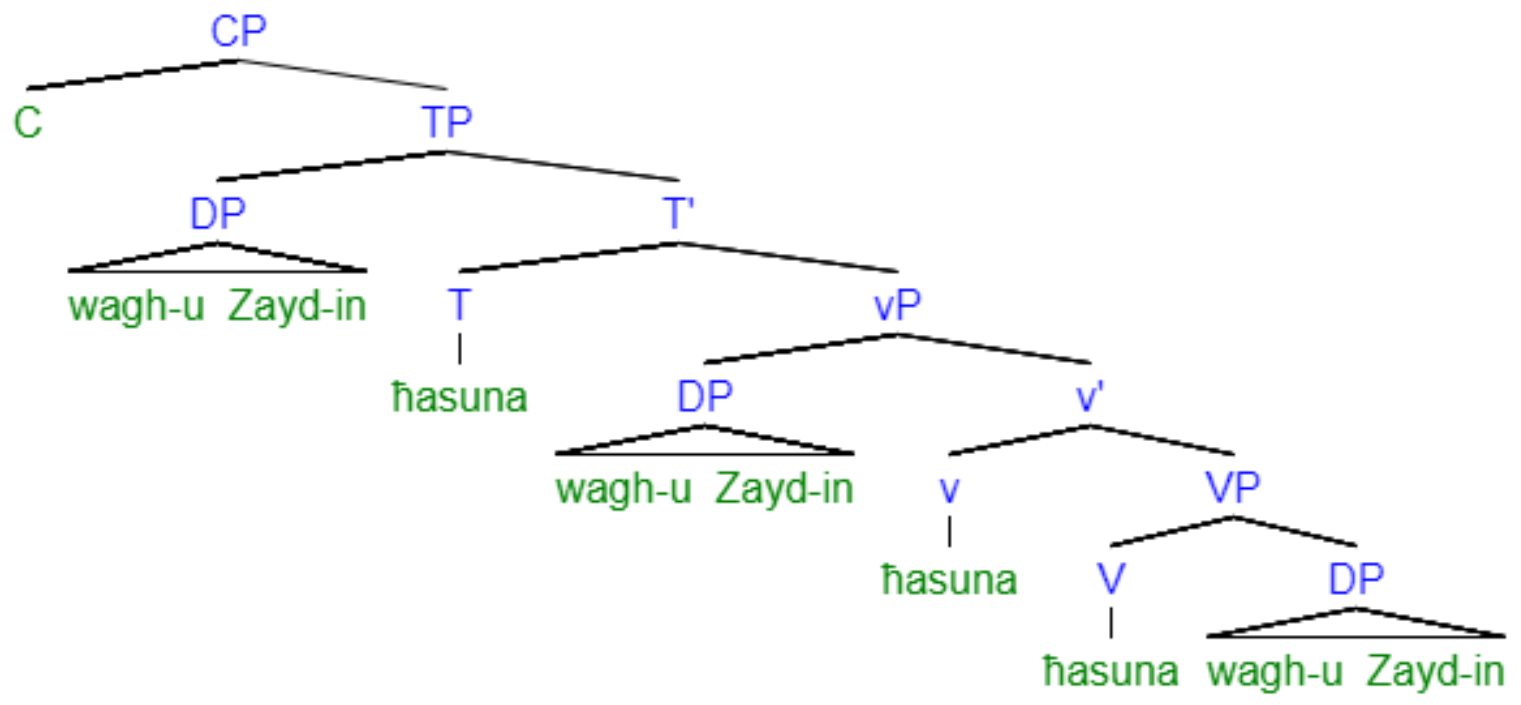

(21)

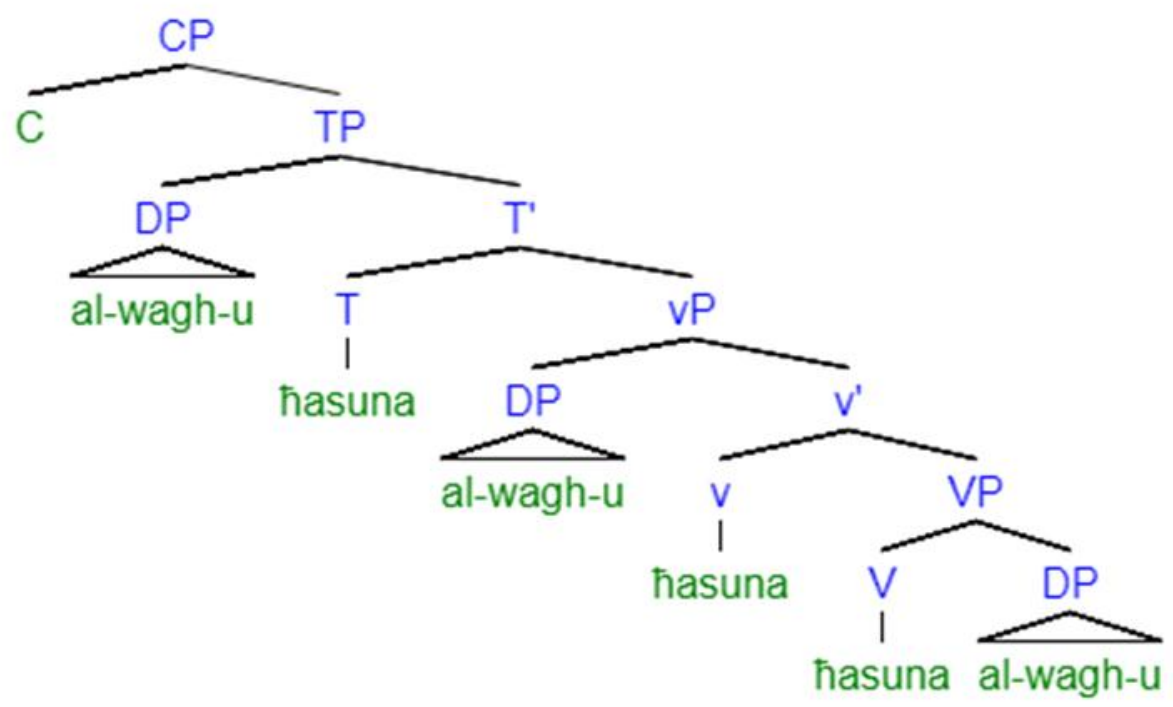

Hence, it can be proposed that fasula is an unaccusative verb. It matches the diagnostics of unaccusative predicates. First, it requires only one argument that is assigned the theta role theme. Its only argument originates as the complement of the lexical verb $\mathrm{V}$, then it is raised to the subject position in order to be assigned 


\section{Language \& Literature}

the nominative case. Second, the unaccusatives in variant $/ \mathrm{u} /$, similar to the unaccusatives in the other two variants of Form 1, allow tamyiiz/ resultative predicates, as shown in the above examples. A resultative predicate is obligatory within the $\Theta$-grid of the verb in F1 Variant $C$, but optional with the other variants of F1. This shows that there is a relationship between phonology and the $\Theta$-grid of the verb. Consider the following verse from Qur'an.

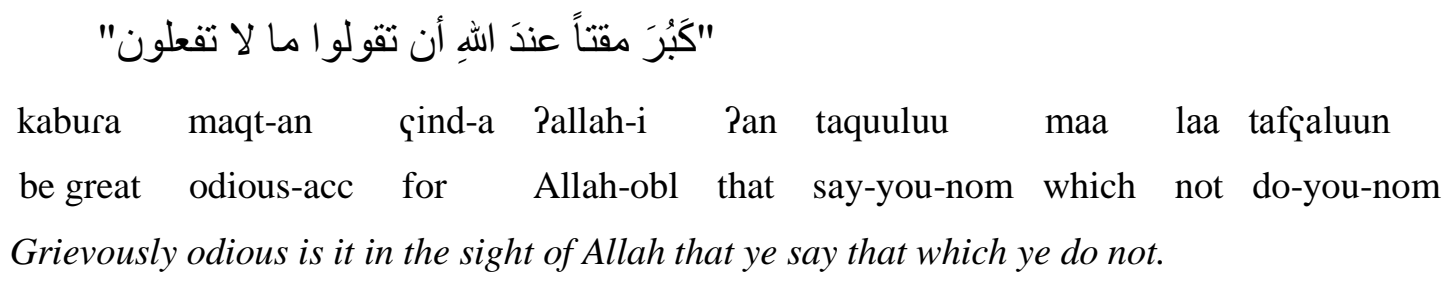

(As-Saff: Verse 1 (translation by Abdullah Yusuf Ali))

maqt-an cannot be moved elsewhere in the sentence and this is one diagnostic of tamyiiz/ resultative predicate; unlike depictive predicates which are mobile and are associated with the arguments of the verb. Furthermore, the semantic relation between the resultative predicate and the verb is very strong that in the translation of the verse it disappears because it is an inherent part of the semantics of the verb.

\section{Form 4 Denominative Verbs PafSala أفقَ}

As for denominative verbs (verbs derived from nouns), adding / $\mathrm{Ra} /$ to the noun creates a new argument. Thus, the argument structure of the resulting verb includes one argument. This is exemplified in a verb like ?aөmara (to bear fruit), which is derived from the noun $\theta$ amar (fruits).

$$
\begin{aligned}
& \text { Paemarat al-fagarat-u } \\
& \text { to bear fruit the tree-nom } \\
& \text { The tree bore fruit. }
\end{aligned}
$$




\section{Language \& Literature}

Furthermore, another group of denominatives shows the entering upon a period of time, getting into a state or condition, obtaining or having something or moving toward a place, as in the examples below.

$$
\begin{aligned}
& \text { Paqfarat al-Pard-u } \\
& \text { to become desert-fem the-land-nom }
\end{aligned}
$$

The land became desert.

$$
\text { Pahrama al-ragal-u }
$$

enter the sacred land the-man-nom

The man entered the sacred land.

$$
\begin{aligned}
& \text { Pazhara al-musafir-u } \\
& \text { enter upon the time of mid-day the-traveler-nom } \\
& \text { The traveler entered upon the time of mid-day. }
\end{aligned}
$$

The representative verbs mentioned in the above sentences exhibit the characteristics of typical unaccusative predicates. These verbs have a single argument that is assigned a Patient or Theme $\theta$-role. It originates as the internal argument of the lexical $\mathrm{V}$, as exemplified in the following tree diagram of sentence (24). 


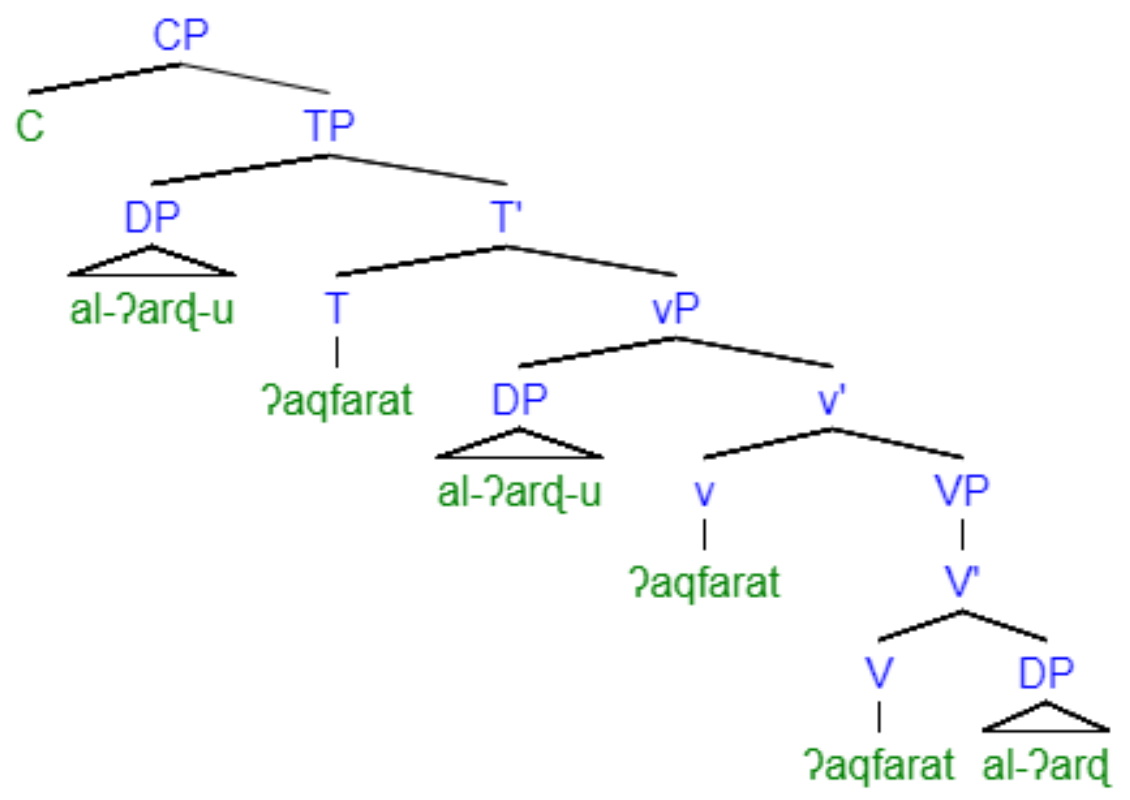

Another evidence that denominative F4 verb is unaccusative is that it does not allow the usage of the adjuncts Samdan and qasdan, the Arabic counterparts of 'deliberately' and 'intentionally', as illustrated below.

$$
\begin{aligned}
& \text { *?aqfarat al-Pard-u Samdan } \\
& \text { become desert-fem the-land-nom deliberately } \\
& \text { *The land became desert delibarately. }
\end{aligned}
$$

\section{Form 9 RifGalla افَّلَّ}




\section{Language \& Literature}

F9 is derived from the third variant in F1 (faSula) by the gemination of the third radical. It mainly shows colors and defects and indicate intensiveness (Wright 1896) such as Piћmarra (to be red) and PiSwagga (to be crooked). Gemination, which usually affect the $\Theta$-grid of the verb by augmenting the number of its arguments, here only signifies intensity. Consider the following paradigm.

$$
\begin{aligned}
& \text { hamura wagh-u al-bent-i } \\
& \text { to be red face-nom the girl-gen } \\
& \text { The girl's face was red. } \\
& \text { Pihmarra wagh-u al-bent-i } \\
& \text { to be red face-nom the girl-gen } \\
& \text { The girl's face was red. }
\end{aligned}
$$

The F9 verb in sentence (30) (Piћmarsa) has the same argument structure as its F1 counterpart in sentence (29) (ћатига), and both can be captured by the following VP-Split trees (Larson 1988 and inter alia). The following trees in (31) and (32) represent a unified analysis for both sentences. The VP is split into the core VP which includes the base verb (立mura) and its complement, whereas the light vP contains the causative morpheme. This morpheme is abstract in the sentence in example (31) but is morphologically realized by the gemination of the third radical in F9, as shown in the sentence in example (32). 


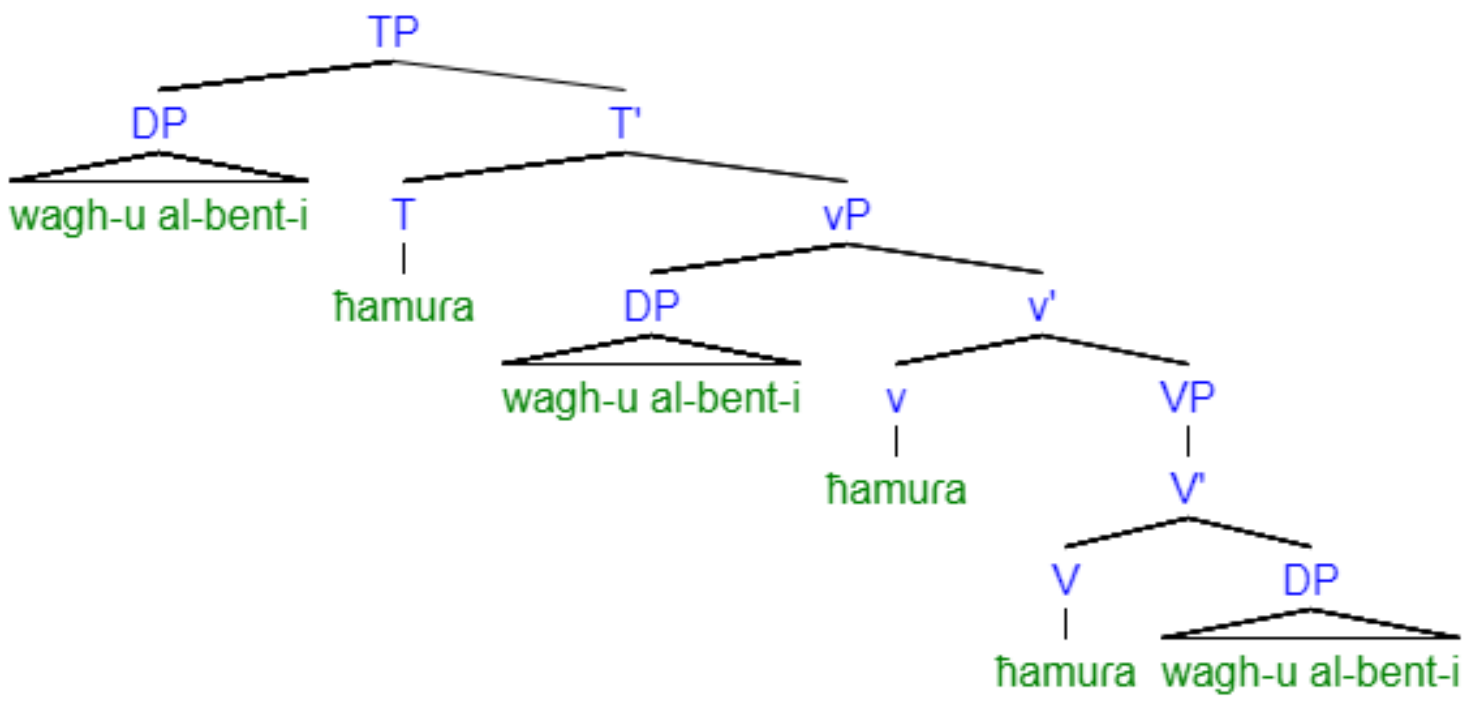

(32)

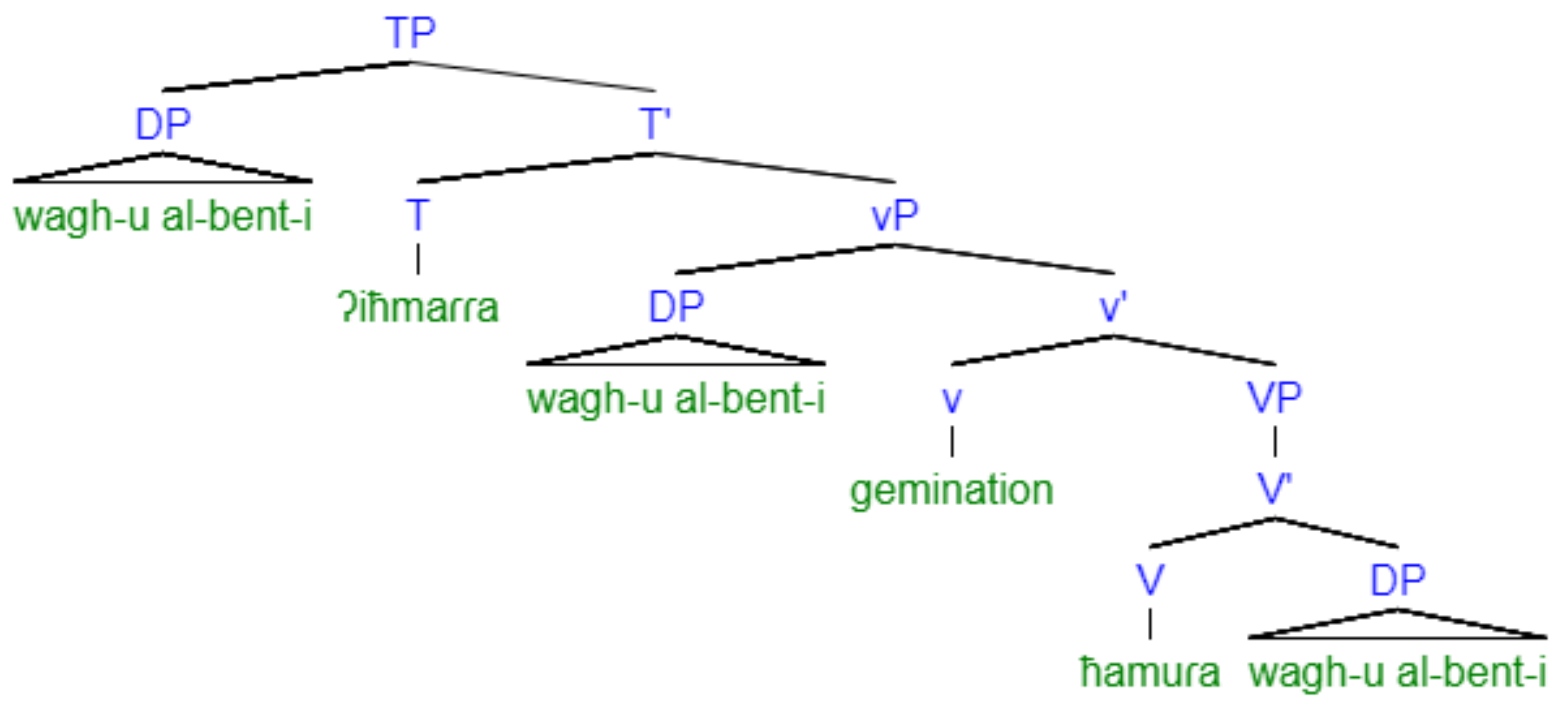

As the verbs in F9 retain the same argument structure of their counterparts in F1 Variant $C$, they exhibit the characteristics of unaccusatives. They require a single argument that is assigned the Patient or Theme theta role, and that originates 


\section{Language \& Literature}

internally in the complement position in the VP. They also allow resultative predicates, as illustrated below.

Pihmarra-t al-bent-u wagh-an
to be red-fem the-girl-nom face-acc
The girl's face was red.

\section{Conclusion}

In conclusion, this paper studies verb forms of the triliteral Arabic verb that display typical traits of unaccusative predicates. Through analyzing their argument structure, the three variants of Form 1 verbs, denominative Form 4 verbs and Form 9 verbs all match the diagnostics of unaccusative predicates. First, the verb requires a single argument that is assigned the Patient or Theme theta role, and that originates internally in the complement position in the VP. In addition, as unaccusative verbs cannot specifically assign the agent theta role to their only DP argument, the usage of adverbs like '(un)deliberately' and '(un)intentionally' generates unmeaningful sentences. Finally, unaccusatives allow resultative predicates. In order to analyze the argument structure of those various verb forms, this study made use of the VP-Split hypothesis, which provided a unified structural analysis of the verbs in both Classical Arabic and Modern English. Hence, this study also proves that argument structure is the same in all languages. Argument structure proves to be a universal property, and the surface structure varies across languages. 


\section{Language \& Literature}

\section{Tables of IPA Symbols Used in the Phonemic Transliteration of Classical Arabic:}

\section{Consonants}

\begin{tabular}{|c|c|c|c|}
\hline Symbol & Example & Symbol & Example \\
\hline $\mathrm{b}$ & bint (girl) & $\hbar$ & huşaan (horse) \\
\hline $\mathrm{t}$ & tuffaahah (apple) & G & cayn (eye) \\
\hline $\mathrm{d}$ & dub (bear) & $\int$ & fams (sun) \\
\hline $\mathrm{k}$ & kitab (book) & 8 & yaalii (expensive) \\
\hline $\mathrm{g}$ & gamal (camel) & $\mathrm{X}$ & xaruuf (sheep) \\
\hline $\mathrm{q}$ & qalam (pencil) & $\mathrm{h}$ & hadiyyah (present) \\
\hline$?$ & Parnab (rabbit) & $Z_{Z}$ & zarf (envelop) \\
\hline ţ & ţaaPir (bird) & $\underline{S}$ & suurah (picture) \\
\hline $\mathrm{d}$ & dufdaç (frog) & $\mathrm{m}$ & maktab (desk) \\
\hline $\mathrm{f}$ & farawlah (strawberry) & $\mathrm{n}$ & nagm/ najm (star) \\
\hline$\theta$ & $\theta$ açlab (fox) & ז & ragul (man) \\
\hline ð & ðayl (tail) & 1 & luçbah (toy) \\
\hline $\mathrm{Z}$ & zaraafah (giraffe) & $\mathrm{y}$ & yadd (hand) \\
\hline $\mathrm{S}$ & subbuurah (board) & $\mathrm{W}$ & walad (boy) \\
\hline $\mathrm{j}$ & jamal (camel) & & \\
\hline
\end{tabular}

Table 1. Consonant phonemes

\section{Vowels}

\begin{tabular}{|l|l|l|l|l|l|}
\hline \multicolumn{5}{|c|}{ Vowels } \\
\hline $\mathrm{i}$ & $\begin{array}{l}\text { short high } \\
\text { front } \\
\text { unrounded }\end{array}$ & $\mathrm{a}$ & $\begin{array}{l}\text { short mid } \\
\text { unrounded }\end{array}$ & $\mathrm{u}$ & $\begin{array}{l}\text { short high } \\
\text { back rounded }\end{array}$ \\
\hline
\end{tabular}

Table 2. Vowel phonemes

- Length of a vowel is indicated by doubling the vowel, as in (kaataba)

- Gemination is indicated by doubling the consonant letter, as in (kattaba)

\section{Abbreviations}




\section{Language \& Literature}

\begin{tabular}{|l|l|}
\hline acc & Accusative case \\
\hline compl & Complement \\
\hline d & Dual \\
\hline fem & Feminine \\
\hline F1 & Form 1 of the triliteral verb \\
\hline F2 & Form 2 of the triliteral verb \\
\hline F3 & Form 3 of the triliteral verb \\
\hline F4 & Form 4 of the triliteral verb \\
\hline F5 & Form 5 of the triliteral verb \\
\hline F6 & Form 6 of the triliteral verb \\
\hline F7 & Form 7 of the triliteral verb \\
\hline F8 & Form 8 of the triliteral verb \\
\hline F9 & Form 9 of the triliteral verb \\
\hline gen & Genitive case \\
\hline LF & Logical Form \\
\hline masc & masculine \\
\hline MP & Minimalist Program \\
\hline nom & Nominative Case \\
\hline pl & plural \\
\hline P\&P & Principles and Parameters \\
\hline sing & singular \\
\hline Spec & Specifier \\
\hline UG & Universal Grammar \\
\hline V & Verb \\
\hline X & variable \\
\hline Y & variable \\
\hline Z & variable \\
\hline & \\
\hline
\end{tabular}




\section{References}

Abd-el-latif, Mohammad Hamasah. (2000). Al-nahw wa-al-delalah:Madkhal li-derasat El-ma'na Al-nahawi El-delali. Cairo: Dar El-shoroq.

Ali, Amani Youssef. (2003). The Minimalist Program Revisited: Evidence from Standard Arabic Phrase Structure. (Unpublished doctoral dissertation). Helwan: Helwan University.

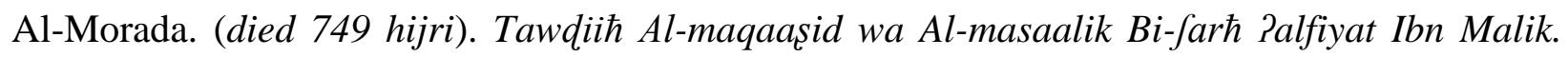
Dar El-Fikr Al-Yarabi, Cairo. Retrieved from https://archive.org/details/tmmsaim (accessed July 20, 2020)

Baker, Mark. (1997). Thematic Roles and Syntactic Structure. In Elements of the Grammar, ed. Liliane Haegemean,73-137. Dordrecht: Kluwer.

Belletti, Adriana. (1988a). The Case of Unaccusatives. Linguistic Inquiry, 19: 1-34.

Bruening, Benjamin. (2002). Unaccusatives and Passives. Retrieved from http://www.ling.udel.edu/bruening/Cources/2001-2/610/Lecture02.pdf (accessed March 12, 2015)

Chomsky, Noam. (1981). Lectures on Government and Binding. Dordrecht: Foris.

Chomsky, Noam. (1982). Some Concepts and Consequences of the Theory of Binding. Cambridge, Mass.: MIT Press.

Chomsky, Noam. (1991). Some Notes on Economy of Derivation and Representation. In Principles and Parameters in Comparative Grammar, ed. R. Freiden, 417-454. Cambridge, Mass.: MIT Press.

Chomsky, Noam. (1993). A Minimalist Program for Linguistic Theory. In Kenneth Hale \& Samuel Jay Keyser (Eds.), The View from Building 20: Essays in Linguistics in Honor of Sylvain Bromberger, (1-52). Cambridge, Mass.: MIT Press.

Chomsky, Noam \& Lasnik, Howard . (1995). The Theory of Principles and Parameters. In Noam Chomsky (Ed.), The Minimalist Program (13-127). Cambridge, Mass.: MIT Press.

Comrie, Bernard. (1978). Ergativity. In Winfred P. Lehmann (Ed.), Syntactic Typology: Studies in the Phenomenology of Language (329- 394). Austin: University of Texas Press.

Edelstein, Elspeth. (2020). English Syntax: A Minimalist Account of Structure and Variation. Edinburgh: Edinburgh University Press. 
Fayyad, Solayman. (1995). Al-nahw El-'asri: Dalil Mobassat li-qawa'id Al-lughati Al'arabiyah. Cairo: Markaz Al-ahram liltargamah wa-al-nashr.

Grimshaw, Jane. (1990). Argument Structure. Cambridge, Mass.: MIT Press.

Haegeman, Liliane. (1997). Elements of the Grammar. In Liliane Haegemean (Ed.), Elements of the Grammar (1-71). Dordrecht: Kluwer.

Hale, Kenneth \& Keyser, Jay. (1991). On the Syntax of Argument Structure. Linguistic Inquiry, 16: 395-420. Cambridge, Mass.: MIT Press.

Hale, Kenneth \& Keyser, Jay. (1993). On Argument Structure and Lexical Expression of Syntactic Relations. In Kenneth Hale \& Samuel Jay Keyser (Eds), The View from Building 20: Essays in Linguistics in Honor of Sylvain Bromberger. (53-109). Cambridge, Mass.: MIT Press.

Hale, Kenneth \& Keyser, Jay. (1998). The Basic Elements of Argument Structure. MIT Press. Retrieved from http://student.bu.ac.bd/mumit/Research/NLP-bib/papers/Hale98.pdf (accessed 12 March 2015)

Hallman, Peter. (2005). Causativity and Transitivity in Arabic. Retrieved from http://peterhallman.com/Causativity.pdf (accessed March 13, 2015)

Harley, Heidi. (2002). Possession and the Double Object Construction. Retrieved from http://www.people.fas.harvard.edu/ ctjhuang/NTNU/Harley.2002.give.pdf Iaccessed March 13, 2015)

Mohamed, Mostafa Thabit. (2014). Accusative Case-Assignment in Double Object Constructions in Standard Arabic: A Minimalist Approach. Asian Social Science, 10: 95105.

Hasan, Abbas. 1964. Al-naћw Al-waafii. Cairo: daar al-ma aarif,.

Ibn Hisham, Abd Allah Ibn Yusuf. (died 761 hijri). Muyni Al-labib Yan Kutub Al-?aYarib. Cairo: Maktabat wa-Matba'at Muhammad 'Ali Subayh wa-Awladuh.

Ibn Hisham, Abd Allah Ibn Yusuf. (died 761 hijri). farћ Juðuur Al-ðahab fi MaSrifat Kalaam AlSarab. Cairo: Al-maktabah Al-tijariyah Al-kubra.

Ibn YaSiif, Mowafaq El-Diin. (died 643 hijri). farh Al-Mofassal. Beirut: Maktabat Al-Nahda AlParabeyyah. 
Koopman, H \& Sportiche, D. (1991). The Position of Subjects. Lingua, 85, Special Issue on VSO Languages: 211- 258. North Holland: Elsevier Science Publishers.

Larson, R. (1988). On the Double Object Construction. Linguistic Inquiry, 19: 335-391. Cambridge, Mass.: MIT Press.

Larson, R. (1990). Double Objects Revisited: Reply to Jackendoff. Linguistic Inquiry, 21: 589632. MIT Press.

McCarhty, John. (1981). A Prosodic Theory of nonconcatenative Morphology. Linguistic Inquiry, 12: 373- 418. Cambridge, Mass.: MIT Press.

Mohammad, M.A. (1989). The Sentential Structure of Arabic. (Unpublished doctoral dissertation). Los Angeles: University of Southern California.

Ne'ma, Foad. Mulakhas Qawa'id Al-lughati Al- 'arabiyah.Cairo.

Ouhalla, Jamal. (1999). Introducing Transformational Grammar: From Principle and Parameters to Minimalism. London: Arnold.

Owens, J. (1988). The Foundations of Grammar: An Introduction to Medieval Arabic Grammatical Theory. John Benjamins.

Owens, J. (2013). The Oxford Handbook of Arabic Linguistics. New York: Oxford University Press.

Perlmutter, David M. (1978). Impersonal Passive and the Unaccusative Hypothesis. Retrieved from

http://journals.linguisticsociety.org/proceedings/index.php/BLS/aricle/view/2198/1968 (accessed March 1, 2020)

Radford, Andrew. (2009). An Introduction to English Sentence Structure. Cambridge: The University Press.

Sibawayh, Amr ibn Qanbar. (died 180 hijri). Al-kitaab. Cairo: Maktabat Al-khangi.

Tucker, Matthew A. (2010). The Morphosyntax of the Arabic Verb: Toward a Unified Syntax Prosody. Retrieved from http://web.stanford.edu/ gribanov/downloads/Tucker-QE.pdf (accessed May 1, 2015)

Wright, W. (1896). A Grammar of the Arabic Langauage (Vols. 1-2). Cambridge: The University Press.

Ya’qoub, Emel Badi'. (1993). Mo'gam Al-awzan Al-sarfeya. Beirut: 'alam Al-kotob. 


\section{Language \& Literature}

نظرية التحليل المقسم لجملة الفعل والأفعال غير الناصبة :دراسة مقارنة بين اللغة الإنجليزية الحديثة وإللفة العربية الفصحى

مروة محمود عبد الواحد

$$
\begin{aligned}
& \text { مدرس مساعد - قسم اللغة الإنجليزية - كلية البنات - جامعة عين شمس } \\
& \text { marwa.mahmoud@women.asu.edu.eg } \\
& \text { تحت إنشراف } \\
& \text { أ.د. وفاء عبد الفهيم بطران } \\
& \text { أستاذ اللغويات- قسم اللغة الإنجليزية - كلية البنات - جامعة عين شمس لهر } \\
& \text { wafaa.batran@women.asu.edu.eg }
\end{aligned}
$$

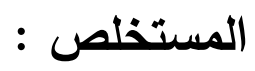

يهدف هذا البحث إلى دراسة وتحليل تصنيفات الفعل الثلاثي المجرد و المزيد التي تتصف بكونها مسند إليه غير ناصب. تقدم هذه الدراسـة الأدلة التي تتبت أن كلا من التصنيف الأول من الفعل الثلاثي بأوزانه الثثلاثة و الأفعال المشتقة من الأسم في التصنيف الرابع بالإضافه إلى التصنيف التاسع كلهم من نوع المسند إليه غير الناصب .و بناءً عليه فإنَّ هذه الدراسة تهدف إلى إثبات أنَّ التركيب الدلالي للفعل لا يتغير بين اللغتين الإنجليزية و العربية بالرغم من الاختلافات الجذرية في تصريف الفعل بين اللغتين لانتمائهما إلى أصسول لُغويـة مختلفة (اللغات السامية و اللغات الهندوأوروبيـة) . بالإضافه لما سبق، تحاول هذه الدراسة إثبات أن نظرية التحليل المقسم لجملة الفعل (لارسن 1988) توفر تحليل تركيبي موحد للتركيب الدلالي للفعل غير الناصب وذلك في اللغة العربية الفصحى كما هو الحال في اللغة الإنجليزية. تتتاول هذه الدراسة تحليل بنية الفعل الثلاثي المجرد والمزيد والتركيب الدلالي لهما طبقاً لنظرية تشومسكي (1981 و 1982 و 1991و 1993).

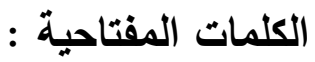

المسند إليه غير الناصب، الفعل الثناثي في اللغة العربية الفصحى، نظرية التحليل المقسم لجملة الفعل، نظرية تشومسكي، نظرية الحد الأدنى 